\title{
Analysis of Corylus pollen season in Poland in 2020
}

\author{
Krystyna Piotrowska-Weryszko', Agata Konarska', Małgorzata Puc ${ }^{2}$, Elżbieta Weryszko-Chmielewska', \\ Małgorzata Malkiewicz ${ }^{3}$, Agnieszka Lipiec ${ }^{4}$, Dariusz Jurkiewicz ${ }^{5}$, Grzegorz Siergiejko ${ }^{6}$, Kazimiera Chłopek ${ }^{7}$, \\ Ewa Kalinowska ${ }^{8}$, Piotr Rapiejko ${ }^{8,9}$ \\ ${ }^{1}$ Department of Botany and Plant Physiology, University of Life Sciences in Lublin, Poland \\ ${ }^{2}$ Institute of Marine \& Environmental Sciences, University of Szczecin, Poland \\ ${ }^{3}$ Laboratory of Paleobotany, Department of Stratigraphical Geology, Insitute of Geological Sciences, \\ University of Wroclaw, Poland \\ ${ }^{4}$ Department of Prevention of Environmental Hazards and Allergology, Medical University of Warsaw, Poland \\ ${ }^{5}$ Department of Otolaryngology with Division of Cranio-Maxillo-Facial Surgery in Military Institute of Medicine, \\ Warsaw, Poland \\ ${ }^{6}$ Pediatrics, Gastroenterology and Allergology Department, University Children Hospital, \\ Medical University of Bialystok, Poland \\ ${ }^{7}$ Faculty of Natural Sciences, Institute of Earth Sciences, University of Silesia in Katowice, Poland \\ ${ }^{8}$ Allergen Research Center, Warsaw, Poland \\ ${ }^{9}$ Department of Otolaryngology with Division of Cranio-Maxillo-Facial Surgery in Military Institute of Medicine, \\ Warsaw, Poland
}

\begin{abstract}
:
In Poland hazel is one of the earliest flowering plants and in phenology it belongs to indicator plants that mark the beginning of early spring. Hazel pollen grains contain allergens that are a cause of pollen allergy during the early spring period. The aim of the present study was to compare Corylus pollen seasons in 2020 in the following 11 cities located in different regions of Poland: Szczecin, Bydgoszcz, Zielona Gora, Wroclaw, Opole, Sosnowiec, Piotrkow Trybunalski, Warsaw, Lublin, Olsztyn, and Bialystok. This research was conducted using the volumetric method and Burkard or Lanzoni pollen samplers. Pollen season duration was determined by the $95 \%$ method. This study analyzed the specific parameters of the pollen season (start, end, peak value, peak date, annual total) and also determined the number of days with a concentration exceeding the threshold values at which the first allergy symptoms in people sensitized to hazel pollen and symptoms in all allergic patients occur, respectively. The hazel pollen season in 2020 began relatively early, between January $11^{\text {th }}$ and February $2^{\text {nd }}$. The season start was recorded earliest in Opole and latest in Olsztyn and Bialystok. The study found that the pollen season started earlier in the western part of Poland than in the eastern regions. The highest maximum Cory/us pollen concentration was recorded in Lublin $\left(388 \mathrm{P} / \mathrm{m}^{3}\right)$, whereas the lowest one in Bydgoszcz $\left(48 \mathrm{P} / \mathrm{m}^{3}\right)$. The maximum daily concentration of Corylus pollen grains was recorded in different periods in the individual cities, while the peak concentration values occurred between January $31^{\text {th }}$ and March $4^{\text {th }}$. The highest risk of allergy in people sensitive to the pollen of this taxon was found in Lublin since the most days with a pollen concentration exceeding the threshold value were observed in this city. Lublin was found to have the highest annual total values and they were 1.6-5.6 times higher than in the other cities. The highest annual pollen sums and peak values as well as the highest number of days with a concentration exceeding the threshold value had also been recorded in Lublin previously.
\end{abstract}

Key words: aeroallergens, pollen concentration, risk of allergy, hazel, 2020

\section{Introduction}

The pollen of hazel (Corylus) is one of the more important sources of allergens in Europe. In Poland
$11 \%$ of people have been found to be sensitized to the pollen of this taxon [1]. A significant number of patients exhibiting symptoms of allergy to Corylus pollen 
has been recorded in Switzerland [2], Hungary [3], and Turkey [4].

Corylus belongs to the family Betulaceae. Alder (Alnus sp.), birch (Betula sp.), and hornbeam (Carpinus sp.) are classified in the same family. Because the pollen of the above-mentioned genera contains allergens showing homology, their simultaneous presence in the air can lead to cross reactions in allergic people [5].

The genus Corylus includes shrubs, e.g. common hazel (Corylus avellana), and trees such as Turkish hazel (Corylus colurna). The abundance of common hazel pollen can be evidenced by an impressive number of pollen grains (over $8 \mathrm{mln}$ ) released by one inflorescence called catkin [6]. During the growing season, hazel sheds pollen earliest of all anemophilous trees and in phenology the beginning of flowering of Corylus avellana is considered to be the beginning of early spring.

The onset and characteristics of the Corylus pollen season greatly depend on weather conditions before and during flowering. Due to the above, large differences are observed in pollen release dates for this taxon [7]. In an earlier study, it was shown that in Poland in the 1950's the beginning of flowering of Corylus female flowers occurred in March [8]. In recent years, on the other hand, the beginning of hazel flowering most frequently took place much earlier, already at the end of January [9, 10]. Corylus pollen production, release, and dispersal are significantly affected by meteorological factors, among them temperature, precipitation, humidity, sunlight hours, and wind speed $[7,11]$.

Many studies have demonstrated that climate warming has an impact on plant flowering times and pollen abundance $[12,13]$. Earlier flowering of plants [11] as well as shortened and more intense pollen seasons are recorded [14].

Aim

The aim of the study was to compare the hazel pollen concentration in the air of selected cities in Poland in 2020.

\section{Material and method}

Measurements of airborne hazel pollen concentration were carried out in Szczecin, Bydgoszcz, Zielona Gora, Wroclaw, Opole, Sosnowiec, Piotrkow Trybunalski, Warsaw, Lublin, Olsztyn, and Bialystok in 2020. Aeroplankton samples were collected using the volumetric method and Burkard or Lanzoni pollen samplers. Microscopic observations were performed on preparations obtained in a 7-day cycle with assessment of 24-hour periods. Pollen concentrations were expressed as the number of pollen grains in $1 \mathrm{~m}^{3}$ of air per day $\left(\mathrm{P} / \mathrm{m}^{3}\right)$. The duration of the hazel pollen seasons was determined by the $95 \%$ method. The start and end of the season were defined as the date when $2.5 \%$ and $97.5 \%$ of the seasonal cumulative pollen count was trapped, respectively. The study compares the start and end dates of the pollen season, maximum concentrations, annual total and the number of days with a pollen concentration of $35 \mathrm{P} / \mathrm{m}^{3}$ and $80 \mathrm{P} / \mathrm{m}^{3}$. The first allergy symptoms in subjects sensitized to hazel pollen and symptoms in all allergic patients occur at these threshold values [15].

\section{Results}

In Poland in 2020 the start of the hazel pollen season occurred between January $11^{\text {th }}$ and February $2^{\text {nd }}$ (tab. 1). The earliest start of the season was recorded in Opole, whereas the latest one in Olsztyn and Bialystok. In the cities located in the western part of Poland (Szczecin, Zielona Gora, Wroclaw), the pollen season began in the middle of January. The pollen season ended in the first week of March (between March $3^{\text {rd }}$ and $7^{\text {th }}$ ) in most of the cities, but in Sosnowiec and Lublin it lasted until March 14 $4^{\text {th }}$, whereas in Bydgoszcz and Olsztyn until March $22^{\text {th }}$ and March $23^{\text {th }}$, respectively. Multiple peaks can be noted in the daily airborne pollen concentrations. High pollen concentrations occurred several times during the pollen season and they were separated by days on which the pollen concentrations were at a low level. The periods of high pollen concentration were similar in most of the cities and they occurred at the turn of January and February, in the middle of February, and at the beginning of March (fig. 1-6). The maximum hazel pollen concentrations were recorded in the individual cities on different dates, between January $31^{\text {th }}$ and March $4^{\text {th }}$ (tab. 1). The seasonal peak values ranged $48 \mathrm{P} / \mathrm{m}^{3}-388 \mathrm{P} / \mathrm{m}^{3}$. The highest pollen concentration was recorded in Lublin, while the lowest one in Bydgoszcz. In the other cities, the peak value was from $98 \mathrm{P} / \mathrm{m}^{3}$ to $178 \mathrm{P} / \mathrm{m}^{3}$. The most days with a concentration exceeding the threshold value of $35 \mathrm{P} / \mathrm{m}^{3}$ were observed in Lublin and Warsaw (13 days), followed by Zielona Gora (11 days) and Piotrkow Trybunalski (10 days). The fewest days with the above-mentioned pollen concentration were recorded in Olsztyn (1 day) and in Szczecin, Bydgoszcz, and Bialystok (2 days). The number of days with a pollen 
Table 1. Characteristics of Corylus pollen season in 2020.

\begin{tabular}{|c|c|c|c|c|c|c|}
\hline \multirow{2}{*}{ Site } & \multirow{2}{*}{$\begin{array}{l}\text { Pollen season period } \\
\text { by the } 95 \% \text { method }\end{array}$} & \multirow{2}{*}{ Peak value $\left[\mathrm{P} / \mathrm{m}^{3}\right]$} & \multirow{2}{*}{ Peak date } & \multicolumn{2}{|c|}{$\begin{array}{c}\text { Days number with concentration } \\
\text { above threshold }\end{array}$} & \multirow{2}{*}{$\begin{array}{l}\text { Annual pollen } \\
\text { sum }\end{array}$} \\
\hline & & & & $35 \mathrm{P} / \mathrm{m}^{3}$ & $80 \mathrm{P} / \mathrm{m}^{3}$ & \\
\hline Szczecin & $15.01-07.03$ & 124 & 31.01 & 2 & 1 & 542 \\
\hline Bydgoszcz & $1.02-22.03$ & 48 & 4.03 & 2 & 0 & 459 \\
\hline Zielona Gora & $15.01-7.03$ & 98 & 31.01 & 11 & 3 & 1168 \\
\hline Wroclaw & $15.01-2.03$ & 154 & 16.02 & 6 & 3 & 677 \\
\hline Opole & $11.01-7.03$ & 132 & 1.02 & 7 & 3 & 917 \\
\hline Sosnowiec & $31.01-14.03$ & 178 & 16.02 & 5 & 1 & 1030 \\
\hline Piotrkow Trybunalski & $20.01-7.03$ & 146 & 16.02 & 10 & 3 & 1124 \\
\hline Warsaw & $16.01-5.03$ & 133 & 16.02 & 13 & 3 & 1260 \\
\hline Lublin & $1.02-14.03$ & 388 & 17.02 & 13 & 7 & 2080 \\
\hline Olsztyn & $2.02-23.03$ & 99 & 4.03 & 1 & 1 & 395 \\
\hline Bialystok & $2.02-6.03$ & 122 & 4.03 & 2 & 1 & 371 \\
\hline
\end{tabular}

concentration of more than $80 \mathrm{P} / \mathrm{m}^{3}$ was highest in Lublin (7 days), whereas in Bydgoszcz no such days were recorded. 1 or 3 days on which the pollen concentration exceeded the threshold value of more than $80 \mathrm{P} / \mathrm{m}^{3}$ were observed in the other cities. The highest annual total value (2080 pollen grains) was recorded in Lublin and it was 1.6-5.6 times higher than in the other cities. In 2020 the fewest hazel pollen grains were recorded in Bialystok (371).

\section{Discussion}

In 2020 the hazel pollen content in the air of Lublin much exceeded the annual pollen sums and maximum daily pollen concentrations of this taxon found in the other 10 cities of Poland. The annual Corylus pollen sum in Lublin was $40 \%$ higher than the total annual pollen count recorded in Warsaw, where the value of this parameter ranked second among the cities in which the study was carried out in the year in question. It is worth noting that in a long-term study the Corylus pollen concentrations were also much higher in Lublin than in other cities of Poland [16].

However, the annual pollen sum shown in Lublin in 2020 reached a record value compared to the study results found in this city in the previous years. The Corylus pollen seasonal curves for the years 2020 and 2019 as well as the average pollen season determined based on the last 10 years are presented for comparison. Clear differences can be seen in the pattern of the seasons and they indicate a much higher Corylus pollen production over the last two years than in the previous years (fig. 6). It can be presumed that the recorded changes are a result of a temperature increase that has occurred in Lublin during the last decades [13, 17]. In 2020 the maximum Corylus pollen concentrations occurred at the studied sampling sites on different dates, between January $31^{\text {th }}$ and March $4^{\text {th }}$. A great variation in the dates corresponding to the highest pollen concentrations was also found in 2018, though the most intense pollen release occurred a month later (March $3^{\text {rd }}$ - April $\left.4^{\text {th }}\right)[18]$.

In 2020 the onset of the hazel pollen season took place relatively early at all the sampling sites in Poland, as it occurred between January $11^{\text {th }}$ and February $2^{\text {nd }}$. The start of this taxon's pollen season was recorded much later in 2019 (February $5^{\text {th }}-$ February $18^{\text {th }}$ ) [19] and in 2018 (January $25^{\text {th }}-$ March $3^{\text {rd }}$ ) [18]. We found that in the three above-mentioned years of the study the season started earliest in the western part of Poland and latest in the eastern regions of the country.

Lublin was shown to exhibit the greatest risk of allergy to Corylus pollen, which is associated with the highest pollen concentration and the highest number of days on which the pollen concentration exceeded the threshold values. In the season studied, there was also a significant risk to allergy sufferers in Warsaw, Zielona Gora, and Piotrkow Trybunalski. Lublin and Piotrkow Trybunalski also belonged to the cities that exhibited the highest risk of allergy to this taxon's pollen in the two previous years $[18,19]$. 
Figure 1. Corylus pollen concentration in Szczecin and Sosnowiec in 2020.

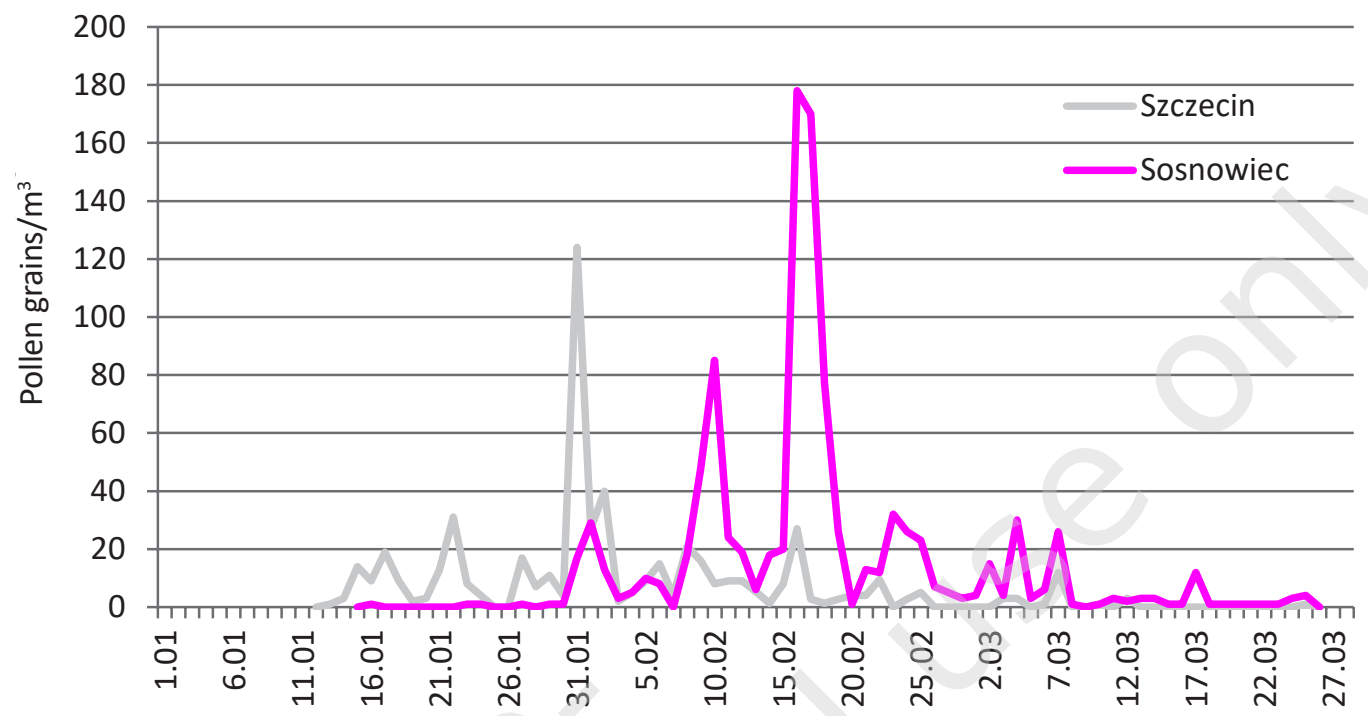

Figure 2. Corylus pollen concentration in Zielona Gora and Opole in 2020.

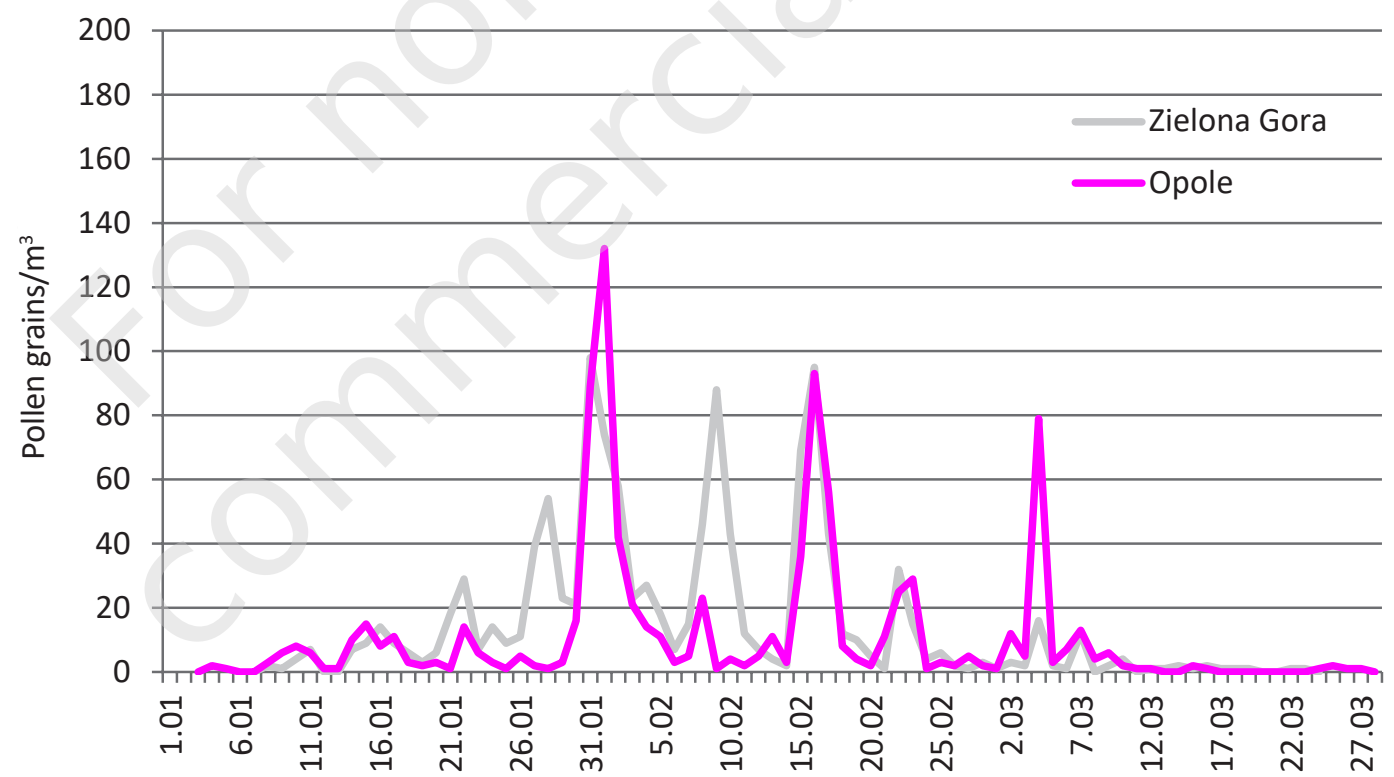

Figure 3. Corylus pollen concentration in Warsaw and Piotrkow Trybunalski in 2020.

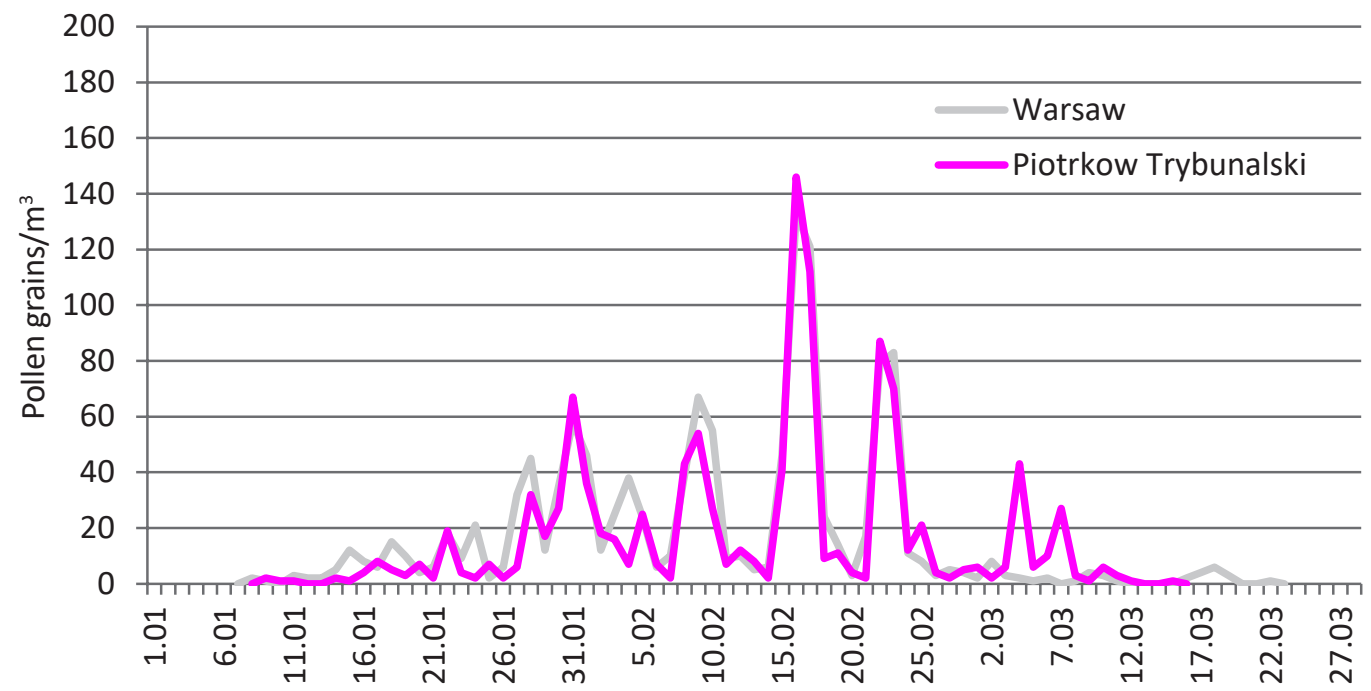


Figure 4. Corylus pollen concentration in Bydgoszcz and Wroclaw in 2020.

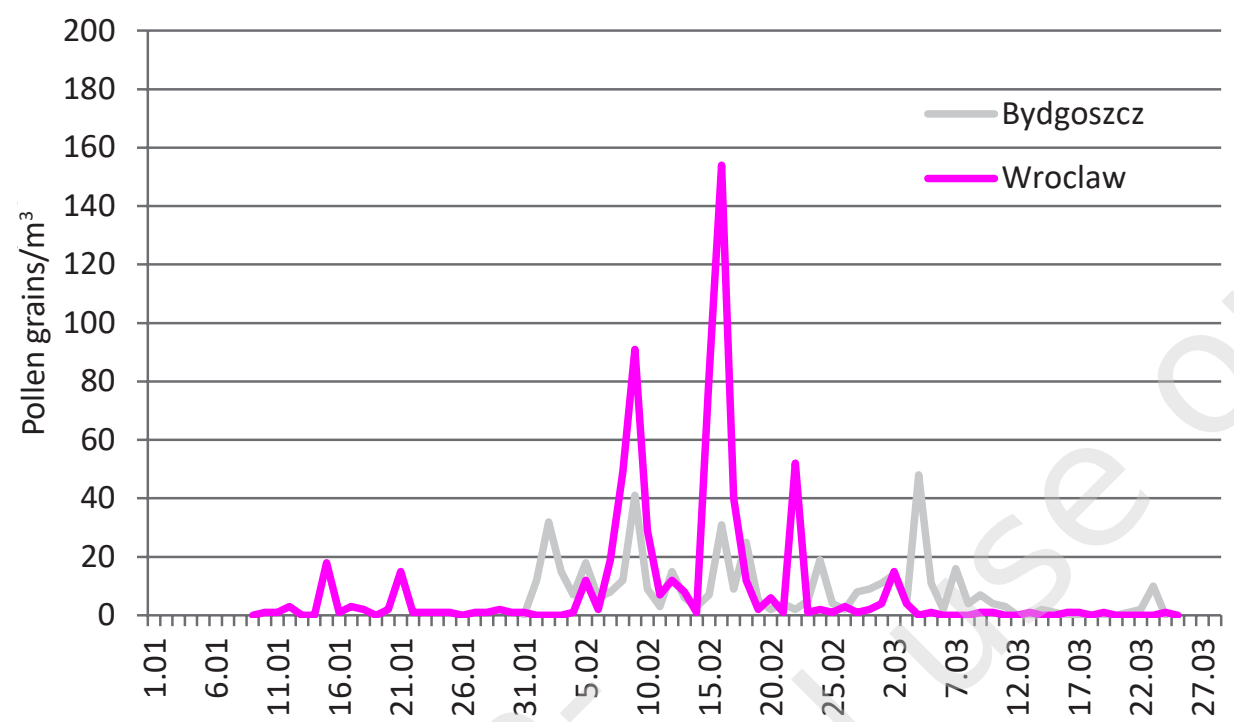

Figure 5. Corylus pollen concentration in Bialystok and Olsztyn in 2020.

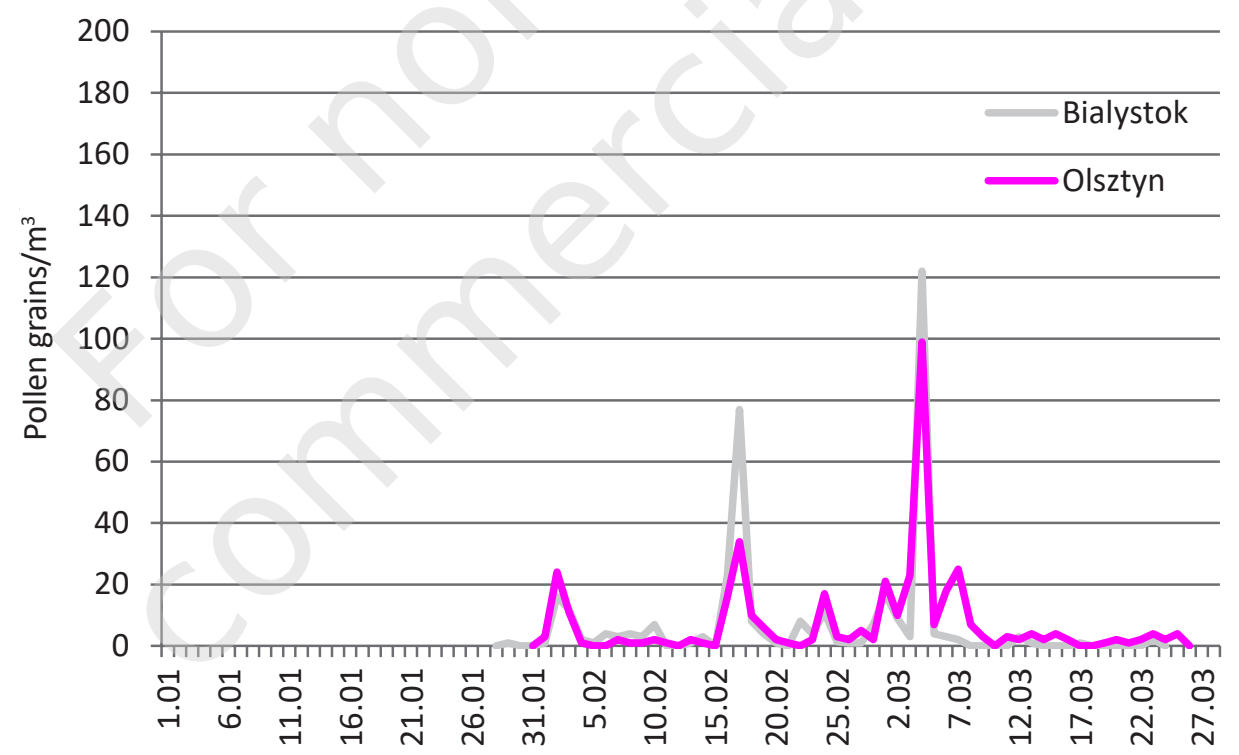

Figure 6. Corylus pollen concentration in Lublin in 2019-2020, mean from 2010-2019. Note: scale is different than in other figures.

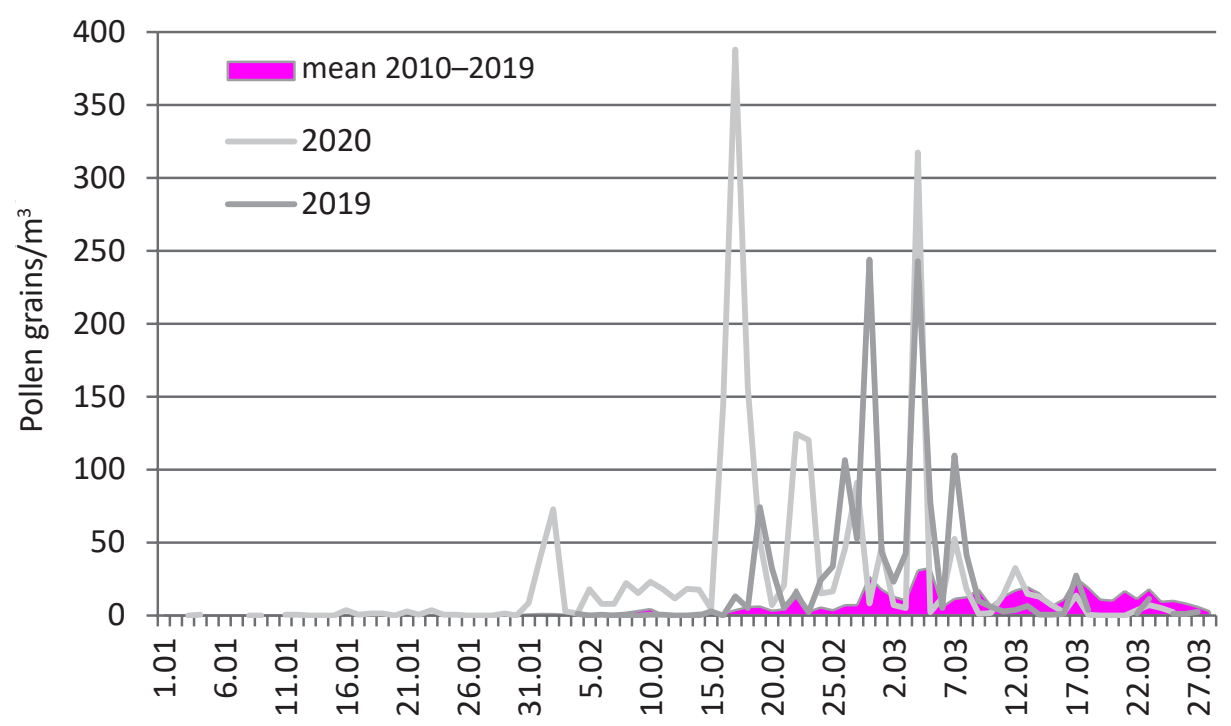




\section{Conclusions}

In 2020 the hazel pollen season started earliest in the western part of Poland (in the second 10 days of January) and latest in eastern Poland (at the beginning of February).

The highest annual pollen sum and peak value were found in Lublin, similarly to the previous years.

The highest risk of allergy to Corylus pollen was found in Lublin, Warsaw, Zielona Gora, and Piotrkow Trybunalski.

\section{References}

1. Majkowska-Wojciechowska B. Pyłek roślin i alergeny sezonowe w Polsce. Alergia Astma Immunologia. 2016; 21(1): 5-15.

2. Frei $T$, Torricelli $R$, Peeters $A G$ et al. The relationship between airborne pollen distribution and the frequency of specific pollen sensitization at two climatically different locations in Switzerland. Aerobiologia. 1995; 11: 269-73.

3. Kadocsa E, Juhasz M. Study of airborne composition and allergen spectrum of hay fever patients in South Hungary (1990-1999). Aerobiologia. 2002; 18: 203-9.

4. Erkara IP, Cingi C, Ayranci $U$ et al. Skin trick test reactivity in allergic rhinitis patients to airborne pollens. Environ Monit Assess. 2009; 151: 401-12.

5. Hauser M, Roulias A, Ferreira F et al, Panallergens and their impact on the allergic patient. Allergy Asthma Clin Immun. 2010; 6(1): 1 .

6. Piotrowska K. Ecological features of flowers and the amount of pollen released in Corylus avellana (L.) and Alnus glutinosa (L.) Gaertn. Acta Agrobotanica. 2008; 61(1): 33-9.

7. Puc M. The effect of meteorological conditions on hazel and alder pollen concentration in the air of Szczecin. Acta Agrobotanica. 2007; 60(2): 65-70.

8. Sokołowska J. Przewodnik Fenologiczny. Wydawnictwo Komunikacji i Łączności, Warszawa 1980.

9. Myszkowska D, Jenner B, Puc M et al. Spatial variations in dynamics of Alnus and Corylus pollen seasons in Poland. Aerobiologia. 2010; 26: 209-21.

10. Piotrowska-Weryszko K, Weryszko-Chmielewska E. Charakterystyka sezonów pyłkowych leszczyny $i$ olszy w Lublinie w 2014 r. Alergoprofil. 2014; 10(2): 21-3.

11. Rodriguez-Rajo FJ, Dopazo A, Jato V. Environmental factors affecting the start of pollen season and concentrations of airborne Alnus pollen in two localities in Galicia (NW Spain). Ann Agric Environ Med. 2004; 11: 35-44.

12. Ariano R, Canonica GW, Passalacqua G. Possible role of climate changes in variations in pollen seasons and allergic sensitizations during 27 years. Ann Allergy Asthma Immunol. 2010; 104(3): 215-22.
13. Weryszko-Chmielewska E, Piotrowska-Weryszko K, Dąbrowska A. Response of Tilia sp. L. to climate warming in urban conditions - phenological and aerobiological studies. Urban For Urban Gree. 2019; 43: 126369.

14. Skjøth CA, Biliniska D, Werner M et al. Footprint areas of pollen from alder (Alnus) and birch (Betula) in the UK (Worcester) and Poland (Wroctaw) during 2005-2014. Acta Agrobotanica. 2015; 68(4): 315-24.

15. Rapiejko P, Lipiec A, Wojdas A et al. Threshold pollen concentration necessary to evoke allergic symptoms. Int Rev Allergol Clin. 2004; 10(3): 91-3.

16. Weryszko-Chmielewska E (ed). Pytek roślin w aeroplanktonie różnych regionów Polski. Wydawnictwo Akademii Medycznej w Lublinie, Lublin 2006.

17. Piotrowska K, Kaszewski BM. The influence of meteorological conditions on the start of the hazel (Corylus L.) pollen season in Lublin, 2001-2009. Acta Agrobotanica. 2009; 62(2): 59-66.

18. Piotrowska-Weryszko K, Konarska A, Kaszewski BM et al. Analysis of Corylus pollen seasons in selected cities of Poland in 2018. Alergoprofil. 2018; 1(14): 21-6.

19. Piotrowska-Weryszko K, Konarska A, Puc M et al. Corylus pollen season in Poland in 2019. Alergoprofil. 2019; 15(1): 16-21.

\section{ORCID}

K. Piotrowska-Weryszko - ID - http://orcid.org/0000-0003-3827-3218

A. Konarska - ID - http://orcid.org/0000-0003-2174-7608

M. Puc - ID - http://orcid.org/0000-0001-6734-9352

E. Weryszko-Chmielewska - ID - http://orcid.org/0000-0001-8410-2757

M. Malkiewicz - ID - http://orcid.org/0000-0001-6768-7968

A. Lipiec - ID - http://orcid.org/0000-0003-3037-232

D. Jurkiewicz - ID - http://orcid.org/0000-0003-3729-2679

G. Siergiejko - ID - http://orcid.org/0000-0003-4084-8332

E. Kalinowska - ID - http://orcid.org/0000-0003-4821-6882

P. Rapiejko - ID - http://orcid.org/0000-0003-3868-0294

Author's contributions: Piotrowska-Weryszko K.: 40\%; other Authors: 6\% each. Conflict of interests: The authors declare that they have no competing interests. Ethics: The contents presented in this paper are compatible with the rules the Declaration of Helsinki, EU directives and standardized requirements for medical journals.

Financial support: Research in Bialystok, Bydgoszcz, Olsztyn, Opole, Piotrkow Trybunalski, Warsaw and Zielona Gora funded by Allergen Research Center Ltd.

Copyright: @ Medical Education sp. z 0.0. This is an Open Access article distributed under the terms of the Attribution-NonCommercial 4.0 International (CC BY-NC 4.0). License (https://creativecommons.org/licenses/by-nc/4.0/), allowing third parties to copy and redistribute the material in any medium or format and to remix, transform, and build upon the material, provided the original work is properly cited and states its license.

Corresponding author:

Krystyna Piotrowska-Weryszko, Assoc. Prof.

Department of Botany and Plant Physiology,

University of Life Sciences in Lublin

20-950 Lublin, Akademicka 15

e-mail: krystyna.piotrowska@up.lublin.pl 